\title{
Kilka uwag o dysydenctwie oraz literaturze antytotalitarnej w Bulgarii
}

\begin{abstract}
Gołek-Sepetliewa Dorota, Kilka uwag o dysydenctwie oraz literaturze antytotalitarnej w Butgarii (A Few Remarks about the Dissident Movements and the Anti-Totalitarian Literature in Bulgaria). „Poznańskie Studia Slawistyczne” 6. Poznań 2014. Publishing House Science and Innovate, pp. 105-118. ISBN 978-83-63795-51-1. ISSN 2084-3011.

The aim of this article is to introduce a characteristic of the dissident movement and the anti-totalitarian literature in Bulgaria in the period 1944-1989. In the early, 90s a group of very important researchers began to focus on an accurate description of a Bulgarian dissident movement and migration literature. The results of researches in the field of history and literary studies do not give a coherent and explicit definition of dissent, dissident movement or migration dissident literature. In addiction recent works in literary studies, are not based on the various paradigms of dissent, but they create new terms and categories to describe the phenomena of cultural and literary period of the People's Republic of Bulgaria from 1944 to 1989. The most popular are: alternative canon, anti-totalitarian literature, alternative literature, illegal literature - and in relation to dichotomies: literature of the PRB, socialist realism, socialist canon, official literature.
\end{abstract}

Keywords: dissident movements; anti-totalitarian literature; People's Republic of Bulgaria; illegal literature; alternative literature; migration literature

Kwestia bułgarskiego dysydenctwa wymaga konfrontacji z problematyką ruchów opozycyjnych, uformowanych w krajach byłego bloku wschodniego. W tego typu ujęciach okazuje się, że przypadek Bułgarii jest szczególny ze względu na brak zorganizowanego oporu społeczeństwa wobec narzuconego systemu komunistycznego, w odróżnieniu od takich krajów, jak Polska, Czechosłowacja, Związek Radziecki czy Węgry. Podejmowane od początku lat 90. ubiegłego wieku w ramach szeroko rozumianej humanistyki projekty badawcze, uznawane za ważne, choć znacznie spóźnione, mają na celu rzetelny opis specyfiki bułgarskiego ruchu opozycyjnego. Żadne dotychczasowe ustalenia historyczne czy literaturoznawcze 
nie przynoszą satysfakcjonującej, koherentnej ani jednoznacznej deskrypcji zarówno kategorii dysydenctwa, jak i literatury dysydenckiej. Co więcej, najnowszy dyskurs literaturoznawczy, borykający się ze spiętrzeniem kwestii spornych narosłych wokół omawianego zagadnienia, tworzy nowe terminy i kryteria oceny zjawisk społecznych i kulturowo-literackich czasu Bułgarskiej Republiki Ludowej 1944-1989. Najczęściej wprowadza się do dyskusji takie pojęcia, jak: kanon alternatywny, literatura antytotalitarna, alternatywna oraz nielegalna. W pracach historycznych padają zgodne stwierdzenia, że do lat 1986-1987 nie istniał zorganizowany ruch dysydencki. Dopiero w latach 1988-1989 powstały zinstytucjonalizowane formy opozycyjne oraz stowarzyszenia, które w sposób realny i niebudzący wątpliwości wpływały na zmiany sytuacji politycznej i kulturalnej w kraju.

W rozważaniach na temat bułgarskiego dysydenctwa często przywoływane są słowa Michaiła Nedełczewa z Wprowadzenia do bułgarskiej części popularnego w krajach postkomunistycznych Stownika dysydentów, dotyczące sytuacji społeczno-kulturowej drugiego półwiecza XX wieku:

Cała rzeczywistość w Bułgarii w okresie socjalizmu może być rozpatrywana jako wielokierunkowy konflikt dwóch kultur - kultury stoickiej normalności i kultury histerycznego komunistycznego patosu. „Bycie normalnym” w sensie przywiązania do tradycji, rodzinnego duchowego dziedzictwa, zasad religijnych oznaczało bycie podejrzanym, ściągnięcie na siebie uwagi służb bezpieczeństwa, znalezienie się w kategoriach nieprawomyślnych (Nedełczew 2007: 40).

Znany bułgarski liberał objaśnia także:

Do lat 1986-87 nie można było w Bułgarii marzyć o mobilizacji czy instytucjonalizacji grup dysydenckich, ponieważ ich działania nie przybrały form prawdziwie publicznych. Najczęściej były to pojedyncze akcje lub działania twórcze, których znaczna część była na wpół anonimowa, realizowano je zaś w niewielkich prywatnych kręgach lub na głębokiej prowincji. Były szybko odkrywane i wyciszane przez dobrze zorientowanych pracowników służb bezpieczeństwa (Nedełczew 2007: 41).

Podkreślając opóźnienie w powstawaniu ugrupowań opozycyjnych, nie można zapomnieć, że silne działania antykomunistyczne w formie zorganizowanego protestu miały miejsce w Bułgarii bezpośrednio po zakończeniu II wojny światowej, w latach 1944-1947. W krajach Europy Wschodniej początek konfliktów z władzą nastąpił dziesięć lat później, tzn. po 1956 
roku. Legalna bułgarska opozycja została fizycznie unicestwiona. Rozbicie Bułgarskiego Ludowego Związku Chłopskiego na czele z Nikołą Petkowem, którego prawomocnie skazano na śmierć w sfingowanym procesie z 1947 roku oraz zdelegalizowanie Partii Radykalno-Demokratycznej Nikoły Muszanowa - to przykłady bezwzględnego traktowania ruchów otwartego sprzeciwu.

W pierwszych latach po 9 września 1944 roku zorganizowano niezwykle sprawny aparat służb bezpieczeństwa, pacyfikujący całe społeczeństwo. Setki tysięcy ludzi znalazło się w obozach pracy przymusowej, tak zwane sądy ludowe podczas pokazowych procesów skazały na śmierć 2720 osób, 1120 zaś usłyszało wyrok dożywotniego więzienia. Na porządku dziennym były wysiedlenia ludności albo osadzanie jej w poprawczych koloniach pracy na wyspie Belene, w miejscowościach Łowecz, Kucijan, Bogdanow Doł, Skrawena, Nożarewo i innych. W książce Pod znakiem BRL-u Celina Juda tak opisuje sytuację elity kulturalnej po zakończeniu wojny:

Zawiłych dziejów bułgarskich elit umysłowych chyba nigdy wcześniej nie cechował taki dramatyzm i nigdy też historia nie naraziła bułgarskiej wspólnoty wartości, kultury czy zbiorowej pamięci na aż tak tragiczne konsekwencje. To właśnie w czasach reżimu komunistycznego władza programowo dyskredytowała wartość i przydatność społeczną intelektualisty kulturowego i wylansowała intelektualistę politycznego, który z dużym zaangażowaniem uczestniczył w tworzeniu nowego systemu i pomagał wypracować sposoby jego funkcjonowania. W pierwszych latach wprowadzania dyktatu robotniczo-chłopskiego intelektualistom kulturowym, a priori naznaczonym piętnem odrzucenia - profesorom uniwersytetu, pisarzom i artystom, którzy sceptycznie podchodzili do tworzonego na ich oczach rytuału socjalistycznej kultury - nie szczędzono upokorzeń. Wielu doświadczyło brutalnego traktowania w czasie przesłuchań (...). Jeśli nawet represyjny stosunek rodzimej władzy do bułgarskich elit intelektualnych nie odbiegał zasadniczo od metod stosowanych przez komunistów w Czechosłowacji, na Węgrzech czy w Polsce, to w interesującym nas przypadku metodyczność i systematyczność działań była znacznie większa i przyniosła dużo bardziej spektakularne efekty (Juda 2003: 42-43).

Tym samym w Bułgarii nie dochodziło do wielkich strajków robotniczych ani do masowych wieców protestacyjnych. Drugi obieg literatury praktycznie nie istniał, podobnie jak samizdat. Nedełczew podkreśla jednak, że w tej perspektywie oglądu ,nie powinno się utrwalać obrazu Bułgarii jako zastygłego bagniska realnego socjalizmu, terytorium nieznającego świadomości obywatelskiej jako przestrzeni naznaczonej wyłącznie rezygnacją i brakiem wolności oraz lizusowskim wiernopoddaństwem" 
(Nedełczew 2007: 40). Rozkwit ruchów opozycyjnych i obywatelskich stowarzyszeń przynoszą lata 1988-1989. Pierwsza legalna organizacja dysydencka Niezależne Stowarzyszenie Obrony Praw Człowieka, której przewodził Ilija Minew, powstała w 1988 roku. W tym samym roku utworzono Społeczny Komitet Obrony Ekologicznej Ruse oraz Klub Poparcia Jawności i Przebudowy z przewodniczącym i późniejszym prezydentem Żelju Żelewem. W 1989 roku założono Niezależną Federację Pracy „Podkrepa”, Komitet Obrony Praw Religijnych, Wolności Sumienia i Wartości Duchowych, Związek Chrześcijański „Spasenie”, Niezależne Stowarzyszenie „Ekogłasnost”, Komitet „273”. W 1989 roku ukazały się dwa czasopisma o charakterze samizdatowym: „Most” i „Głas”, publikujące teksty, które stanowczo lekceważyły zasady socrealizmu i nie były poddawane cenzurze czy kontroli redakcyjnej. Promowały one literaturę o typie alternatywnym, wyróżniającą się na tle ekspansywnej i powszechnie akceptowanej twórczości ideologicznej.

Powszechnie wiadomo, że w badaniach nad dysydenctwem byłych krajów socjalistycznych stosunkowo często akcentuje się znaczenie dzieł powstałych na emigracji, tworzonych poza głównym, oficjalnym nurtem literatury, a należących do największych osiągnięć literackich. Warto w tym miejscu wymienić nazwiska emigracyjnych autorów: Milana Kundery, Czesława Miłosza, Aleksandra Sołżenicyna, Tomasa Venclovy.

$\mathrm{Na}$ gruncie bułgarskim silne związki pomiędzy literaturą oficjalną, powstającą w ojczyźnie, a dokonaniami artystów, którzy opuścili kraj, nie były aż tak oczywiste. Galin Tihanow twierdzi, że literatura emigracyjna była ,zupełnie nieobecna na horyzoncie percepcji i daleka od ukonstytuowania pewnej organicznej całości z literaturą stanowiącą główny nurt w kulturze kraju" (Tihanow 1995: 157). Co więcej, przed 1989 rokiem, jak pisze Juda, „konotacje określeń emigracja, emigrant uwikłano w fatalne, głównie polityczne związki. Bułgarska władza bezwzględnie i skutecznie blokowała informacje dotyczące losów artystów oraz ich dokonań powstających na obczyźnie" (Juda 1998: 197). Zdaniem Bożidara Kunczewa, działania propagandowe $\mathrm{w}$ drugiej połowie XX wieku miały na celu całkowite zanegowanie istnienia bułgarskiej literatury emigracyjnej (Kunczew 1993: 92). Dopiero na początku lat 90 . XX wieku podjęto kroki zmierzające do rewizji utrwalonego przez miniony ustrój chaotycznego oblicza emigracji. Anulowano sądowe orzeczenia z zaocznych, niejednokrotnie fingowanych 
procesów emigrantów, w czasie których często zapadały wyroki śmierci. Równolegle pojawiły się próby naukowej systematyzacji i typologizacji zjawisk emigracyjnych lat 1944-1989 oraz interpretacji postaw autorów i twórczości powstałej w diasporze.

Na ogół w opracowaniach powtarzają się tezy, że polityka kulturalna BRL naznaczyła decyzje o wyjeździe z ojczyzny piętnem hańby, emigrantów uznano za zdrajców, wrogów, nazwiska artystów wyrzucono z oficjalnego obiegu literackiego, natomiast informacje o aktywności intelektualnej na obczyźnie skutecznie blokowano, istotnie ograniczając wpływ emigrantów na społeczeństwo w kraju za żelazną kurtyną. Wyjazd z Bułgarii w okresie tak zwanej pierwszej i drugiej fali emigracyjnej oznaczał podróż w jedną stronę, z nikłą szansą na powrót. Granicę udało się przekroczyć garstce intelektualistów, głównie pod pretekstem wyjazdu służbowego, stypendium czy stażu zagranicznego, a także dzięki pomocy zagranicznych przyjaciół - często przy użyciu sfałszowanych dokumentów. Czynniki te przesądziły o specyfice bułgarskiej emigracji, którą cechuje, jak określa to Celina Juda, „dramatyczna atomizacja” (Juda 2009: 75).

Z perspektywy początku drugiej dekady XXI wieku prace naukowe, dotyczące artystycznej spuścizny emigracji, stanowią istotny składnik współczesnego literaturoznawstwa bułgarskiego. Trudno jednak mówić o skondensowanych wnioskach oraz zwartej koncepcji zjawiska. Pojawiające się wciąż nowe opracowania tematu, kolejne próby interpretacyjne, są korygowane i uzupełniane przez następne głosy w dyskusji. W obecnym modelu systematyki literatury w diasporze wykorzystuje się głównie pojęcie fal emigracyjnych ${ }^{1}$. Ożywiona od początku lat 90 . XX wieku, bardzo ważna,

${ }^{1}$ Nikołaj Aretow wyróżnia trzy bułgarskie fale emigracyjne po II wojnie światowej. Pierwsza miała miejsce bezpośrednio po zakończeniu działań wojennych. Kraj opuszczają głównie intelektualiści-dziennikarze, więc teksty pisane na obczyźnie mają luźny związek z literaturą (Christo Ognjanow, Stefan Popow, Tonczo Karabułkow, Petyr Uwaliew, Stefan Gruew, Stojan-Konstantin Władimirow Danew, Żeni Zaimowa). Kolejna fala obejmuje okres od lat 50. XX wieku do lat 80., wśród emigrantów politycznych są intelektualiści i twórcy (Georgi Markow, Władimir Kostow, Rumjana Uzunowa, Nikoła M. Nikołow, Dimityr Inkiow, Atanas Sławow, Cwetan Marangozow, Cetan Todorow i Julia Kristewa, Christo Jawaszew, Ljubomir Kanow, Dimityr Boczew. Ostatnia fala po 1989 roku, związana z upadkiem muru berlińskiego (za cezurę można także uznać rok 1985 - a więc początek pierestojki), ma charakter masowy. Bułgarię opuszczają głównie młodzi ludzie, kierujący się względami ekonomicznymi (Aleksandyr Andreew, Władisław Todorow, Złatko Enew, Zachari Karabaszliew, Alek Popow, Wiktor Paskow, Ałbena Stambołowa, Nikołaj Atanasow, Dimityr Dinew, Ilija Trojanow, Kapka Kasabowa) (Аретов 2009a). 
lecz nade wszystko burzliwa wymiana poglądów, prowadzona wśród elit intelektualnych, nie doprowadziła do przejrzystego opracowania bułgarskiej przeszłości, nie stworzyła spójnego opisu ruchów ani działań opozycyjnych, nie ustaliła w sposób bezsporny listy dysydentów. Podejmowanie starania, naznaczone gwałtownymi sporami oraz niemożnością wypracowania wspólnego stanowiska, Żelju Żelew podsumował ironicznie ostrymi słowami: „дисидент - почти мръсна дума” (,,dysydent - słowo prawie obrzydliwe") (Иванова 1997: 37). Zdanie byłego prezydenta podziela Natalia Christowa, badaczka bułgarskiego ruchu dysydenckiego, która uznaje, że skutki, jakie wywołała idea napisania obszernego, międzynarodowego Slownika dysydentów, przyczyniły się do kompromitacji tego pojęcia w Bułgarii (Христова 2004: 115). Badania prowadzone były w bardzo emocjonalnej atmosferze, pełnej kontrowersji i złośliwej wymiany zdań. Ostatecznie spora grupa znanych opozycjonistów bułgarskich odmówiła włączania ich nazwisk w tworzone listy.

Historia Slownika jest dosyć złożona, warto ją jednak pokrótce przypomnieć, ponieważ odegrała znaczną rolę w postrzeganiu zjawiska opozycyjności przez Bułgarów. W listopadzie 1996 roku w Podkowie Leśnej z inicjatywy polskiego Ośrodka KARTA odbyła się konferencja „Czas dysydentów", w której uczestniczyli przedstawiciele 13 państw byłego obozu wschodniego. Tam zrodził się pomysł napisania Slownika, który miał objąć 23 kraje. Prace nad nim, koordynowane przez KARTĘ, ukończono w 2007 roku, a publikacja objęła biogramy czołowych postaci ruchów opozycyjnych w krajach komunistycznych w latach 1956-1989. W konferencji pod Warszawą wziął udział Michaił Nedełczew, przedstawiciel stowarzyszenia „Grażdanin”, w którym uruchomiono badania nad ruchem dysydenckim i antykomunistycznym w Bułgarii. Koordynował prace nad przygotowaniem listy nazwisk twórców opozycyjnych, spełniających kryteria określone przez projektodawców Slownika, a później podane w wątpliwość przez bułgarskich obserwatorów, intelektualistów, naukowców i artystów.

Na łamach prasy rozgorzała burzliwa dyskusja na temat rozumienia pojęcia dysydent zaproponowanego przez pomysłodawców Stownika, obnażała ona także niedostatki i ułomności międzynarodowego projektu. Stworzone kryteria bowiem nie pozwalały określać mianem nonkonformisty członków partii komunistycznych, głoszących odmienne poglądy w ramach struktur partyjnych ani też krytyków systemu politycznego, wyrażających 
swój sprzeciw już po demokratycznym przełomie. Innym decydującym kryterium był zasięg społecznego oddziaływania opozycyjnych poglądów dysydenta. W rozumieniu projektodawców Słownika opozycjonista powinien otwarcie wygłaszać swoje poglądy i wyrażać dezaprobatę wobec panujących zasad. Powinien być znany w szerszym środowisku społecznym oraz uczestniczyć w tworzeniu zorganizowanych form walki z komunizmem.

Przyjęte założenia sprawiły, że wielu znanych ofiar minionego porządku politycznego nie można było potraktować jako dysydentów, a sporządzona na potrzeby międzynarodowego projektu lista bułgarskich pisarzy opozycjonistów podlegała ostrej krytyce. Michaił Nedełczew niejednokrotnie był zmuszony bronić zasad wydawniczych Stownika oraz zaproponowanego wykazu dysydentów. W 1998 roku na łamach prasy wypowiadał, między innymi, następujące słowa:

Ważne jest, aby dać wyobrażenie o skali dysydenctwa w Bułgarii, zaprezentować ludzi należących do różnych grup społecznych i udowodnić, że nasz kraj nie był wiernym satelitą Związku Sowieckiego. Dysydenctwo to ,życie-nie-w-kłamstwie”. Oczywiście, nie istnieją kryteria absolutne, ale staraliśmy się wybrać osoby, które zostały poddane mitologizacji, których teksty zintensyfikowały nastroje opozycyjne. Kierując się tym tokiem myślenia, jest zupełnie naturalne, że do naszego spisu trafiła Błaga Dimitrowa, dr Żelew, Georgi Markow (Стойчева 1998)².

Jak zaznaczono, nie wszyscy w Bułgarii zgodzili się z tak definiowaną kategorią dysydenctwa. Ewgenija Iwanowa, autorka znanej książki Българското дисидентство 1988-1989 (Bułgarskie dysydenctwo 1988-1989), objaśnia tytułowe pojęcie bardzo szeroko: „najogólniejszą charakterystyką dysydenctwa jest protest moralny" (Иванова 1997: 12), przypominając znane słowa Sołżenicyna i Havla o niemożności życia w kłamstwie. Nedełczew i Iwanowa przywołują nawet te same wypowiedzi słynnych twórców emigracyjnych, ale rozbieżne interpretacje prowadzą ich do odmiennych wniosków.

Natalia Christowa uważa, że sposób prowadzenia debaty na temat dysydenctwa w ostatnich dwudziestu latach doprowadził do wytworzenia niewłaściwej atmosfery w środowisku, dlatego duża grupa intelektualistów nie chce być z nim kojarzona i wyraża sprzeciw wobec prób włączania ich

\footnotetext{
2 Tłumaczenia autorki - o ile nie zaznaczono inaczej.
} 
nazwisk do powstających rejestrów opozycji (Христова 2004: 118). Christowa zwraca także uwagę na specyficzną formę protestu intelektualistów bułgarskich przeciw komunizmowi. Twierdzi, że cechował ją zwykle brak politycznych deklaracji, zamykanie się w kategoriach wyboru indywidualnego, wierność własnemu kodeksowi etyki, odrzucenie (totalitarnych przyp. aut.) form organizacji życia społecznego, zasad narzucanych przez władzę, głoszenie haseł wolności w sferze literatury i sztuki (Христова 2004: 120). Wśród twórców stosujących indywidualne matryce opozycji wymienia poetów Konstantina Pawłowa, Stefana Canewa, Nikołaja Kynczewa, Borisa Christowa, Aleksandra Gerowa, Aleksandra Wutimskiego, Radoja Ralina, Dimitra Korudżiewa, Borisa Dełczewa, Asena Christoforowa, malarza Dimitra Kozakowa-Nerona, karykaturzystów Borisa Dimowskiego i Todora Conewa, scenarzystę Christo Ganewa, a także Błagę Dimitrową i Georgiego Markowa.

Bezkompromisowa postawa, niezbyt powszechna w okresie BRL, dla wielu oznaczała walkę o zachowanie ludzkiej godności. Wierność własnemu kodeksowi moralnemu wymagała odwagi ze względu na represyjny charakter działań władz państwowych, służb bezpieczeństwa, milicji. Taka koncepcja oporu, zdaniem Christowej, nie została jednak zrozumiana, a jej wpływ na życie społeczne był lekceważony przez ostatnie dwadzieścia lat (Христова 2004: 120). Do działań dysydenckich lat 60. XX wieku w Bułgarii można zaliczyć publiczne odczytywanie wierszy na uniwersytetach, placach głównych miast, w klubach, prywatnych domach. Uczestniczyli w nich poeci Konstantin Pawłow, Lubomir Lewczew oraz Stefan Canew, co przyniosło im ogromną popularność, ale i te specyficzne działania twórcze zostały szybko zabronione przez władze.

Do Bułgarii dotarły również echa Praskiej Wiosny, a reakcją na wydarzenia w Czechach była publikacja dwóch tomów poetyckich o charakterze satyrycznym Radoja Ralina Люти чушки (Ostre papryczki) i Marko Ganczewa Бягащо дърво (Uciekające drzewo). Wiersze wyrażały niezgodę na ideologizację życia, Ralin zaś dodatkowo ośmieszył przywódcę bułgarskiego narodu, Todora Żiwkowa. Niedługo po publikacji nakład obu tomików został wycofany i w dużej części zniszczony. Zdarzała się także niesubordynacja twórców teatralnych. Satyryczny spektakl Improwizacje według scenariusza Ralina i Walerego Petrowa, będący humorystyczną refleksją na temat statusu twórcy socjalistycznego, wywołał entuzjazm publiczności 
i niezadowolenie cenzury, która bezzwłocznie wycofała przedstawienie. W 1964 roku po wystawieniu sztuki Emiła Manowa Грешката на Авел (Przewinienie Abla), uznanej przez Todora Żiwkowa za politycznie niepoprawną, zamknięto teatr w Dimitrowgradzie. Ponownie udało się go otworzyć dopiero w 1972 roku. U schyłku lat 60. poddano surowej krytyce sztukę Nedjałko Jordanowa Hие сме на 25 (Mamy 25 lat), ponieważ autor przeciwstawił obraz ,młodych” i „starych” komunistów.

Dziesięć lat późnej, pod koniec lat 70., w bułgarskim środowisku literackim miało miejsce ważne wydarzenie, nazywane współcześnie „skandalem Sołżenicyna”. Związek Pisarzy Bułgarskich na wieść o przyznaniu Nagrody Nobla Aleksandrowi Sołżenicynowi wystosował oficjalny protest wobec decyzji międzynarodowego jury. Pismo nie zostało podpisane przez pięciu pisarzy komunistów: Christo Genewa, Walerego Petrowa, Goczo Gaczewa, Marko Ganczewa oraz Błagoja Dimitrowa, który w ogóle był przeciwny jego napisaniu. Zmuszeni do wyjaśnień literaci tłumaczyli się nieznajomością dorobku literackiego rosyjskiego twórcy, niemniej jednak doświadczyli represji zawodowych za „brak dyscypliny”.

Do spisu dzieł ważnych i duchowo niezależnych, uznawanych przez komunistyczne władze za wrogie, włączana jest powieść Błagi Dimitrowej z 1981 roku pt. Лuщe (Twarz), która została potępiona i skonfiskowana. Taki sam los spotkał publikację naukową Żelju Żelewa Faszyzm. W obu przypadkach autorzy aluzyjnie podawali w wątpliwość głoszony przez władze i propagandę system społeczny, obnażając istotę reżimu komunistycznego. Najdobitniej jednak o brutalności i bezwzględności bułgarskich służb bezpieczeństwa, działających także poza szczelnie chronionymi granicami Bułgarii, świadczą emigracyjne losy pisarza i eseisty Georgiego Markowa, zamordowanego w Londynie w 1978 roku, autora sławnych, odczytywanych w niezależnych zachodnich radiostacjach Zaocznych reportaży o Butgarii, które niczym wiwisekcja obnażały świat za żelazną kurtyną.

Omawiając przejawy sprzeciwu wobec władzy w Bułgarii i ich odbicia w sztuce, należy także zwrócić uwagę na studia literaturoznawcze z ostatnich kilku lat, pośrednio lub bezpośrednio dotyczące tematyki dysydenctwa. Zaproponowane przez badaczy koncepcje wynikają ze współczesnych tendencji do rewidowania i redefiniowania kanonu, otwierając perspektywę nietradycyjnej interpretacji procesu historycznoliterackiego drugiej połowy XX wieku. Prace nad rewizją wcześniejszych ustaleń naukowych trwają 
przede wszystkim w dwóch ośrodkach badawczych - w Bułgarskiej Akademii Nauk i Nowym Uniwersytecie Bułgarskim. W 2009 roku zorganizowały one dwie ważne konferencje dotyczące nowego odczytywania literatury lat 1944-1989: Literatura antytotalitarna: przezwyciężanie mentalności totalitarnej, w dwudziestą rocznicę upadku muru berlińskiego i Kanon socjalistyczny/kanon alternatywny. Oficjalne i nieoficjalne $w$ butgarskiej literaturze między latami 1944 i 1989. Do udziału w projektach zaproszono, oprócz badaczy, również pisarzy dysydentów Dimityra Boczewa i Cwetana Marangozowa oraz dziennikarzy Christo Christowa, Milena Radewa i Wesełę Kulewą.

Uczestnicy sympozjów podkreślali coraz rzadsze używanie pojęcia literatura dysydencka i upowszechnianie się takich terminów, jak kanon alternatywny, literatura antytotalitarna, literatura alternatywna, literatura nielegalna w opozycji do pojęć literatura BRL, realizm socjalistyczny, kanon socjalistyczny, literatura oficjalna. Postulowano, by do literatury alternatywnej - w dosyć szerokim jej ujęciu - zaliczyć wszelkie teksty podważające normy kanonu socjalistycznego, dzięki czemu znalazłoby się dla niej miejsce w rozległym polu między literaturą oficjalną i antytotalitarną. Tom pokonferencyjny BAN-u, opublikowany w 2009 roku, poświęcono kulturowej specyfice Bułgarii lat 1944-1989. Władimir Atanasow twierdzi:

Badania dotyczące tego okresu obejmują obszary, które są charakterystyczne dla myślenia i życia antytotalitarnego: 1) dysydenctwo duchowe ${ }^{3}$ (Konstantin Pawłow, Aleksandyr Gerow, Błaga Dimitrowa, Boris Christow, Radoj Ralin, Stefan Canew i inni); 2) dysydentów-emigrantów (Georgi Markow, Christo Ognjanow, Stefan Popow, Rumjana Uzunowa, Stefan Marinow Jowew, Dimityr Boczew, Lubomir Kanow, Cwetan Marangozow) oraz 3) literaturę tworzoną w warunkach więziennych i/lub w obozach komunistycznych (Josif Petrow, Zmej Gorjanin, Asen Christoforow) (Атанасов 2010).

Literatura antytotalitarna, za której początek uznaje się umownie rok 1947, miałaby według Atanasowa kompensować na płaszczyźnie artystycznej ogromną lukę historyczną w bułgarskiej świadomości społecznej, wytworzoną przez brak znaczących wydarzeń, takich jak czerwcowe powstanie

${ }^{3}$ Badania nad tym obszarem literatury antytotalitarnej przeprowadził Płamen Dojnow. W swojej najnowszej książce wspomina o ,dysydenctwie intelektualnym” poetów: Konstantina Pawłowa, Nikołaja Kynczewa, Binio Iwanowa, Stefana Geczewa, Iwana Teofiłowa, Iwana Dinkowa, Christo Fotewa, Iwana Canewa, Ekateriny Josifowej, Borisa Christowa (Дойнов 2012). 
w Berlinie Wschodnim (1953), Rewolucja Węgierska (1956), Poznański Czerwiec (1956), Praska Wiosna (1968), utworzenie polskiego ROPCiO, grudzień 1970 roku w Gdańsku i Gdyni, powstanie KOR-u (1976), Układ Warszawski i wprowadzenie stanu wojennego w Polsce w 1981 roku, działalność NSZZ „Solidarność” (Атанасов 2010). Jej definicja - konstruowana w pracach badaczy bułgarskich na przeciwstawieniu literatury opozycyjnej literaturze totalitarnej - zawiera teksty, których autorzy odrzucają techniki artystyczne o podłożu ideologicznym. Nie bez znaczenia pozostaje fakt, że literatura tego typu objęta była zakazem publikacji, a jej rozpowszechnianie groziło represjami. Jak pisze Cweta Trifonowa:

W czasie konferencji pojawiły się propozycje definiowania pojęcia literatury antytotalitarnej nie tylko jako alternatywy wobec kanonu socjalistycznego, lecz jako ,innej” literatury XX wieku - jako pamięci zła, broniącej indywidualnej tożsamości, mówiącej o problemach ludzkich w warunkach totalitarnego zniewolenia językiem odrzucającym utopię kolektywistyczną (Трифонова 2009).

Znany literaturoznawca bułgarski Wichren Czernokożew dokonuje następującej interpretacji:

Antytotalitarna to taka literatura (w możliwie szerokim znaczeniu pojęcia literatura), która, myśląc inaczej, dzięki swoim specyficznym środkom wyrazu artystycznego i/lub $\mathrm{z}$ racji charakteru dokumentalnego, bierze w obronę brutalnie ograniczane prawa i wolności obywatelskie. Nieznośna jest dla niej nawet sama idea dehumanizacji człowieka. To literatura na przekór, która należy wyłącznie do siebie samej. Literatura na przekór (lub obok) oficjalnej totalnej kontroli nad wszelkimi sferami życia człowieka w wymiarze społecznym i indywidualnym; na przekór prześladowaniom, represjom, terrorowi, strachowi, na przekór skrajnej ideologizacji, na przekór skrajnej polityzacji, militaryzacji i centralizacji władzy. (...) Zadaniem antytotalitarnej literatury jest przybliżanie zagubionego autentyzmu naszego własnego życia. I dopiero w drugiej i trzeciej kolejności autentyzmu historii literatury i kultury, autentycznej, intensywnej i codziennej odpowiedzialności. (...) Literatura antytotalitarna przywraca godność ludzką, zdobywa się na wysiłek wypowiedzenia tych uniwersaliów kulturowych, dzięki którym życie ludzkie posiada wartość; aby nie stawać się cząstką uprzednio nakreślonej geometrii totalitarnej, będąc raz ofiarą, kiedy indziej współuczestnikiem. To wysiłek ludzki bycia wolnym nawet w warunkach totalitarnego zniewolenia (Чернокожев 2009: 14-16).

Podobnie literaturę antytotalitarną postrzega Nikołaj Aretow, podkreślając, że jest to konstrukcja post factum, dotychczas nieugruntowana w dyskursie literaturoznawczym. Wymaga także doprecyzowania ram 
czasowych, do których się odnosi, ponieważ może obejmować rozległą perspektywę czasową, trzy różne okresy historycznoliterackie: czas rządów totalitarnych, zamykający się w umownych datach 1947-1989; lata po zmianach ustrojowych oraz dziesięciolecia przed zakończeniem II wojny światowej (Аретов 2009b: 27-28). Sporna jest kwestia rozumienia pojęcia literatury antytotalitarnej: według badacza określenie to nasuwa skojarzenia z ,literaturą, która jest przeciw literaturze totalitarnej”, a nie przeciw totalitaryzmowi. W konsekwencji termin zakładający domyślnie wskazaną opozycję, jednocześnie odrzucałby obszary pozostające poza nią. Konieczne jest zatem doprecyzowanie, które zredukuje dychotomię i zakwestionuje pojęcie literatury antytotalitarnej (Аретов 2009b: 28).

Milena Kirowa wskazuje na niebezpieczeństwo truizmów w spóźnionej dyskusji na temat redefinicji kanonu literackiego lat 1944-1989 i w rozważaniach nad istnieniem literatury antytotalitarnej jako koherentnym i możliwym do opisu zjawiskiem, granicami, historycznym sensem pojęcia oraz miejscem w kanonie literackim (Кирова 2009: 2). Wszystko to nie zmienia faktu, że z perspektywy początków XXI wieku prace nad nowym odczytaniem bułgarskiej tradycji kulturowej i reinterpretacją kanonu artystycznego lat 1944-1989 w kierunkach zaproponowanych przez bułgarskie ośrodki badawcze są bardzo istotne. Spójny opis zjawisk dysydenckich oraz dysydenckiej literatury emigracyjnej, a także nowe odczytanie kanonu z perspektywy istnienia literatury alternatywnej i antytotalitarnej, daje szansę na nowy ogląd procesu historycznoliterackiego w Bułgarii tamtego okresu, uwypuklając mało znane obszary dokonań artystycznych.

\section{Literatura}

Juda C., 1998, Emigracyjne biografie butgarskich pisarzy - ucieczka czy exodus z konieczności?, w: Z polskich studiów slawistycznych, red. H. Dalewska-Greń, J. Rusek, J. Siatkowski, Warszawa, s. 197-202.

Juda C., 2003, Pod znakiem BRL-u. Kultura i literatura bulgarska w pulapce ideologii, Kraków.

Juda C., 2009, Biogramy strażników pamięci o „niegdyś wolnej Butgarii” - reprezentantów pierwszej fali powojennej emigracji butgarskiej (1944-...), w: Stowiańskie diaspory. Studia o literaturze emigracyjnej, red. C. Juda, Kraków, s. 73-82. 
Kunczew B., 1993, Literatura emigracyjna - świadectwo tyranii, przeł. H. Karpińska, „Literatura na Świecie” nr 9, s. 92-94.

Nedełczew M., 2007, Wprowadzenie, przeł. H. Karpińska, w: Slownik dysydentów, t. 2, Warszawa, s. 40-45.

Tihanow G., 1995, Literatura emigracyjna a wewnatrzkrajowy proces literacki. Uwagi o butgarskim postmodernizmie, przeł. A. Cimała, w: Postmodernizm w literaturze i kulturze krajów Europy Środkowo-Wschodniej, red. H. Ivaničková, D. Fokkema, Katowice, s. 155-165.

Аретов Н., 2009а, Българската емигрантска литература: поглед от дома, $<$ http://www.slovo.bg/showwork.php3?AuID=38\&WorkID=16629\&Level=1>, 02.05.2013.

Аретов Н., 2009b, Непретенциозната проза на Асен Христофоров и проблемът за антитоталитарната литература, „Литературна мисъл” $\mathrm{nr}$ 1, s. 27-50.

Атанасов В., 2010, „Антитоталитарната литература”: (u) реставрацията на тоталитаризма, „Български език и литература” $\mathrm{nr} 6,<\mathrm{http} / / /$ liternet.bg/publish/ vatanasov/antitotalitarnata.htm>, 10.05.2013.

Чернокожев В., 2009, Антитоталитарната литература: памет за злото, отговорност за бъдещето, w: Антитоталитарната литература: преодоляване на тоталитарния манталитет, red. В. Чернокожев, Б. Кунчев, Е. Сугарев, Софиа, s. 13-22.

Дойнов П., 2012, Алтернативният канон. Поетите, Софиа.

Христова Н., 2004, Специфика на българското дисидентство, „Исторически преглед" nr 3-4, s. 115-141.

Иванова Е., 1997, Българското дисидентство 1988-1989, Софиа.

Кирова М., 2009, Българската антитоталитарна литература?, „Култура” $\mathrm{nr} 43$, s. 2.

Стойчева М., 1998, Михаил Неделчев брои дисидентите, Желев - рицарите на кръглата маса, „Капитал” nr 32, <http://www.capital.bg/politika_i_ikonomika/ bulgaria/1998/08/15/246059_mihail_nedelchev_broi_disidentite_jelev_-_ricarite_ na/>, 10.05.2013.

Трифонова Ц., 2009, Национална научна конференция „Антитоталитарната литература: преодоляване на тоталитарния манталитет”, „Български език и литература" $\mathrm{nr} 3$, <http://liternet.bg/publish/ctrifonova/nacionalna.htm>, 10.05.2013. 
